\title{
Art of Storytelling and the Role of Memory in the Novels of Morrison's Beloved and Louise Erdrich's Tracks
}

\author{
C. L. Shilaja \\ Associate Professor, Department of English, Sathyabama University. ORCID: oooo-ooo3- \\ 4267-4719. Email: sherlinji@yahoo.co.in
}

Received August 8, 2016; Revised March 3, 2017; Accepted March 10, 2017; Published May 7, 2017.

\begin{abstract}
Storytelling provides an emotional fulfillment both for the narrator and the listener. The paper aims to explore the significance of storytelling and the role of memory in selected works of recent American fiction of Louise Erdrich's Tracks and Toni Morrison's Beloved which speaks about the historical experience of Native Americans in dispossession and the long-term effects of slavery. In literary texts, memory often becomes a starting point for a painful therapeutic process of regeneration of one's roots in order to survive. The painful memories of Afro-Americans and Native Americans as a result of racialized trauma are purged through storytelling and in recounting it as a collective experience between people. Storytelling brings them together engaging them collectively in the events of their lives. As the past and present often overlap with one another it enables them to retrieve their suppressed past. Retrieving the past and sharing their traumatic story gives the opportunity for recovery. Morrison and Erdrich perform the role of a storyteller in narrating the unaccounted through their text since modern communities have no access to the oral narratives of their own past. Storytelling unearths repressed memories in order to find ways of dealing with the pain they cause. Although the writings in the novels of Toni Morrison and Louise Erdrich depict two very different cultures, the Afro-American and the Native American, the trauma which damages the self in their characters is very much similar. This process of narration is essential for the survivors to come to terms with their experience. This narration ultimately creates a sort of emotional distance from the event and makes it less threatening for the characters to reflect upon. It is to be remembered that the authors make use of this technique of storytelling not just to heal the fractures of the readers in the modern psyche but also to rewrite a part of history forgotten by preserving the historical data, their cultural values and the Afro-American and Native American ideas.
\end{abstract}

Keywords: Morrison, Erdrich, storytelling, memory, trauma

\section{Introduction}

As a novelist who has set her fiction with care in key periods of black U.S. history, Morrison has in reality dedicated her literary career to ensuring that black experience as a result of slavery would be neither left to interpretation solely at the dictates of whites, nor to an academic history that records only the hard impersonal facts. She has succeeded in this by placing the characters of her novels in the positions American society had designed for African Americans and revealing their lives as they endured, coped with or reacted to, the effects of the racism that had its birth in the institution of slavery.

Erdrich's and Morrison's art of storytelling in the novels transmit their past and present tribulations. Though the Afro-American and Native American cultures are quite different cultures

(c) AesthetixMS 2016. This Open Access article is published under a Creative Commons Attribution Non-Commercial 4.0 International License (http://creativecommons.org/licenses/by-nc/4.o/), which permits non-commercial re-use, distribution, and reproduction in any medium, provided the original work is properly cited. For citation use the DOI. For commercial re-use, please contact editor@rupkatha.com. 
in the United States yet their oral literature plays a major role in shaping their written literature. Their cultures have been preserved over the centuries through the medium of literature. These stories enforce the idea that though recollecting is painful yet those who suffered must not repress their troubles. The writers draw on oral traditions of storytelling as a method towards achieving healing. The storytelling itself can heal as the positive role of words, both spoken and written can both resist as well restore the physical and cultural losses suffered.

Afro-American and Native American communities, as it is widely known, had an oral tradition where experiences, information and the stories were passed down from one generation to another. In oral traditions, the stories are told from memories of the people, and sometimes the story gets modified with the change of narrators. Moreover, these oral histories were more dynamic than the written histories as they kept up with the culture and history of its people alive.

The writers revisit their past to make sense of their individual and communal experiences of pain and suffering which is internalized or personified by their characters. Louise Erdrich, like Morrison achieves an oral quality within her written work by including characters who tell stories to one another as well as the reader, favoring the first person's voice frequently weaving stories in non-chronological pattern with multiple narrators. Her characters are multidimensional and entertaining while communicating the positives and negatives of Native American life in the twentieth century. Her novels are about the dissolution of culture and the need to turn back to tradition and cultural values. She places great emphasis in the need to turn back to the culture which could bring healing and understanding to the characters.

Both Toni Morrison and Louise Erdrich use a circular, open-ended style narrative which emphasize the power of memory as well as resist domination. The retelling of the story is done in pieces, by different narrators and from different point of time, which helps in confronting the victims. Healing takes place when the victims are confronted and stories are shared of their traumatic pasts, using narration as the means of reconnecting to others. Louise Erdrich and Toni Morrison share an interest in portraying live and experience of women, children and minority groups who have been neglected. Tracks and Beloved reflect the lives of the characters subjugation and displacement inflicted on them by a culture that is not their own. The stories passed on by Morrison and Erdrich enforce that remembering is painful, but those who suffered must not forget in order to recover. It is to be remembered that the authors make use of this technique of storytelling not just to heal the fractures of the readers in the modern psyche but also to rewrite a part of history forgotten by preserving the historical data, their cultural values and the Afro-American and Native American ideas.

Toni Morrison has attracted a lot of attention in the past three decades as an essayist and a novelist. Toni Morrison's novels spring from personal, subjective experiences, despite being presented in an objective manner. As a daughter of Southerners, who migrated to the North in the early part of the twenty first century, and brought up in a close-knit three-generational family, storytelling of all kinds, including ghost stories, animal tales, and yarns of magical happenings were important facets of her home-life education. The stories African Americans had told and those written from the eighteenth century to the present are stories of displacement, alienation, humiliation, suffering, violence, and death. Through slavery, they had experienced not only the exploitation of their bodies and untold psychological damage but also fragmentation of their self.

For more than thirty years, Toni Morrison has been commenting on her fiction and narrative strategies. Anderson (2013) depicts the relationship between language and power in the book titled Spectrality in the Novels of Toni Morrison which argues that "Morrison uses this story to 
illustrate the responsibility that comes with the manipulation of language because it is in the writer's hands, like the bird"(p.146). She has stated that her writing is a co-creation between author and reader. This venture of Morrison is indisputably integral to all her fiction. Morrison's works provide both a continuation and a "filling in of gaps" of the earlier works of her people. In much the same way, Rosenblatt (2014) in Impact of Racism on African American Families: Literature as Social Science maintains that "Toni Morrison talked about her emphasis on black culture (including black language)...as she conceptualized it seems to be partly in response to, in defense against and constrained by the racial system" (p.13).

Toni Morrison's agony at not being able to live in a community with common stories to tell and share from one generation to the other, made her find a medium through novel. As Morrison explains, novels are political, and they function as a modern way of keeping communal stories alive:

We don't live in places where we can hear those (old communal) stories anymore; Parents don't sit around and tell their children those classical, mythological archetypal stories that we heard years ago. But new information has got to get out and there are several ways to do it. One is the novel . . . . It should be beautiful, but it should also work. It should have something in it that enlightens; something in it that opens the door and points the way. Something in it that suggests what the conflicts are. ("Rootedness" 341)

\section{Historical Memory and Healing Narratives in Toni Morrison's Novels}

In Trauma, Memory and Subjectivity, Schreiber states that "Each of Morrison novels explores manifestation of self and home, building on each other to retell the story of African American trauma"(1). The novelist engages the readers in her narration that causes them to identify themselves with the characters. Such narrations could have a cathartic effect on the readers. So in a way, in the process of reading, the reader himself becomes part of storytelling, unraveling and collaborating. The narrative technique and the technique of plot construction employed by Morrison force the readers to attain their own reconstruction of the events in the unfilled spaces of the text. In other words, the fragmented parts of the stories are pieced together. Hence remembering or rememory is a conscious, deliberate act, and remembering the past is a creative process and in fact an effort to find the truth. The novelist makes use of the memory as a main narrative structure in all her novels. Both the character and the reader are involved in this process.

Contemporary research on the treatment for post-traumatic stress syndrome indicates that a moral support and compassion from companionship helps victims towards healing. But the most crucial part of healing involves unavoidable confrontation with the original trauma, and feeling the pain again which both the listener and the speaker find difficult to go through. This study primarily applies the theory put forward by the renowned psychologist Judith Lewis Herman on Trauma and Recovery (1992). Ideas by the famed psychologist form the basis for the present study in explaining the concept of storytelling and role of memory. The traumatic symptoms of victims and an understanding of the psychological trauma are some of the concepts the book deals with in detail. It also encompasses individual experience in a broader political frame, arguing that psychological trauma can be understood only in a social context. 
Psychoanalytic approach of Herman helps one to understand with a better perception, the human psyche in an individual character. Herman states that psychological trauma can be understood only in a rather social context. She further affirms that "the restoration of social bonds begins with the discovery that one is not alone" (215) and those who have experienced similar events can understand them. Oral tradition of telling stories is a way for communities to heal themselves when the traumatized person is disconnected from their personal past and cultural origin. Toni Morrison explores communal story telling for cathartic recovery in her novel Beloved. "Sethe learned the profound satisfaction Beloved got from storytelling. It amazed Sethe because every mention of her past life hurt. Everything in it was painful or lost" (69). The plot of Toni Morrison's novel Beloved, explore the various ways in which the stories are shared and how the healing actually takes place. Small stories are shared to the extent that they collectively construct subject positions for themselves. They also include positions in the society other than that of subjugation.

Eventually the psychologist Herman reveals that, "the survivor reclaims her own history and feels a renewed hope and energy for engagement with life" (195). She also states that "The ultimate goal, however, is to put the story, including the imagery, into words" (177). Morrison emphasizes that healing is made possible by these characters sharing their past experiences with one another and by nurturing a coalition that takes place on the basis of their subjective positions.

The oral quality in Morrison's narratives put emphasizes on the need for telling the stories. In retrieving the culture through storytelling, the writers reclaim the fragmented selfhood. The novel Beloved by Toni Morrison is, the story about a run-away slave, Sethe. Sethe's former owners track her and her children down at the home of her mother-in-law on knowing that she had time to kill only one of her four children before the rest were caught. The narrative makes an attempt to understand the nightmare and trauma created by slavery that would cause Sethe to murder her daughter rather than allow her to experience it.

Sethe, initially, could not bring herself to talk about her past "because every mention of her past life hurt. Everything in it was painful or lost. She and Baby Suggs had agreed with each other without saying so that it was unspeakable; to Denver's inquiries Sethe gave short replies or rambling incomplete reveries" (Beloved 58). Sethe's circles around the subject of her past in due course avoiding of "pinning" down her story, "Sethe knew that the circle she was making around the room, him, the subject, would remain one. That she could never close in, pin it down for anybody who had to ask" (163).

The horror of the slave past is shown initially by the appearance of the baby ghost, later in the manifestation of the fully-grown Beloved. Sethe must confront her past so that she may recover from trauma. To Sethe the future was a matter of keeping the past safely at a distance. Only in Beloved's resurrection Sethe was able to look back and interpret the past. This troubling past or trauma is represented by the word "rememory," in the text, which is used throughout the novel. The characters constant struggle to "beat back the past," which intrudes in their lives and causes a haunting pain is physically represented by the appearance of Beloved.

The oral tradition of Black English expects the reader to fill in those gaps with communal knowledge. As Morrison states in an interview to Claudia Tate(1983), "My writing expects, demands participatory reading, and that I think is what literature is supposed to do. It's not just about the story, it's all about involving the reader. The reader supplies the emotions. The reader supplies even the color, some of the sound. My language has to have holes and spaces so the reader can come into it" (Tate 164). The text plays a vital role in documenting and testifying the 
unspeakable horrors of slavery through participatory language. Morrison achieves an oral quality within her written work by including characters who tell stories to one another as well as to the reader, favoring the first person's voice. Through articulation of these stories, the listeners can understand and empathize with them in their grief. This process also helps to facilitate reconnection with one's social environment thereby allowing the victim to reclaim the suppressed traumatized self.

Sethe, initially could not bring herself to talk about her past "because every mention of her past life hurt. Everything in it was painful or lost. She and Baby Suggs had agreed with each other without saying so that it was unspeakable; to Denver's inquiries Sethe gave short replies or rambling incomplete reveries" (Beloved 58). Sethe, with the help of Paul D, finally begins to discover a sense of self-worth. Simonetta Diena in her article "Private Memories and Historical Studies" emphasizes that "We should understand more deeply the meaning of the survivor's guilt toward those who have not survived particularly if they were his closest relatives, parents, spouses, children" (5). Sethe's past and fragments in her memory are put in a coherent story with Paul D's support. Sethe admits that "her story was bearable because it was his was well - to tell to redefine and tell again. The things that neither knew about the other - the things neither had word-shapes for - well, it would come in time..."(Beloved 99)

Morrison's novel retrieves community as having the potential to create a positive, dynamic space for difference, thus distancing itself from notions of black power that endorse separatism. The above conversation suggests that in the sharing of stories not only does one gets cultural enrichment but a healing too. The novels aim towards reader's involvement in their story and for them to be transformed through the process much in the same way the characters of the novels are transformed through the understanding they gain through storytelling and song. When readers listen to one another empathy does turn tears to laughter. Morrison attempts to portray how society moulds and alters its individuals. In Beloved, Morrison portrays Baby Suggs as a nurturing, distinctive communal figure. Baby Suggs, Sethe's mother-in-law, who though left physically and emotionally handicapped by the slave life knew - "how to dance in the sunlight" (Beloved 141).

Sharing stories and exchanging experience since time immemorial is noted as a prominent source of cultural enrichment. In addition to the characters sharing stories, one finds the reader also participating in these stories that Morrison creates. The reader's participation along with her protagonists in unraveling the story is greatly encouraged by Morrison. Little by little, the reader picks up the information and pieces it together and, in doing so, participates in the communal effort of reading the stories.

The readers find that witnessing an event like story telling is a means of healing. A classic example is the healing taking place in the clearing with the ceremony led by Baby Suggs. She places a plea before the children, men and women to listen and to watch each other:

Let the children come! . . . let your mother hear you laugh . . . let the grown men come. . . Let your wives and your children see you dance ....' Finally she called the women to her. 'Cry' she told them. 'For the living and the dead ... .' and without covering their eyes the women let loose. It started that way: laughing children, dancing men, crying women and then it got mixed up. Women stopped crying and danced; men sat down and cried; children danced, women laughed, children cried. . . . (Beloved 87). 
It is apparent that Sethe experiences the ritual of sharing at the Clearing where the women healed one another. Sethe was exorcised of her past through the voices of the women which spoke the unspeakable thoughts:

For Sethe it was as though the Clearing had come to her with its heat and simmering leaves, where the voices of women searched for the right combination, the key, the code, the sound that broke the back of words (261).

When they finally come to translating their memories into words, Morrison demonstrates that, "the collective sharing of that information heals the individual - and the collective” (Herman 1997, 106).

In Beloved the community awareness of the tragic experience of slavery is a burden that the black community needs to relieve itself of. On the individual level, gaining collective freedom calls for re-memorizing one's ancestral heritage of sharing stories. Thus, individual identity is closely related to the communal identity. It requires going back to one's roots, which in turn restores her into the community. For Toni Morrison, it is the Afro-American community that helps in the reclamation of the identity. In an interview with Mckay Nellie, Toni Morrison talks about traditional storytelling,

I am not experial, I am simply trying to recreate something out of an old artform in my books -- the something that defines what makes a book "black". And that has nothing to do with whether the people in the books are black or not. The open-ended quality that is sometimes a problematic in the novel form reminds me of the uses to which stories are put in the black community. The stories are constantly being told, constantly being imagined within a framework.

The mutual understanding, and compassion that stems from common history, contributes to the feeling of a wholeness without which the formation of individual identity within the collective identity would not be achievable.

In enabling Sethe to have her experience articulated, shared or validated she gives herself an opportunity to speak. Sethe's past and fragments in her memory are put into a coherent story with Paul D's support. Paul D comes forward to bear witness to Sethe's stories, he asks her to "Jump, if you want to, 'cause I'll catch you, girl. I'll catch you 'fore you fall. Go as far inside as you need to, I'll hold your ankles. Make sure you get back out" (Beloved 46). Although the novel doesn't explain the phrases "Jump", "go as far as you want" his offer denotes that he is encouraging her to explore her past trauma, as he is there for her to share her story. Paul D and Sethe are able to share their memories of slavery because "The encounter with other who has undergone similar trials dissolves feeling of isolation, shame and stigma” (Herman 215).

Paul D and thirty women from the community engage in group therapy which helps Sethe to integrate her individual pain into that of the larger community. When the women reach 124 Bluestone Road "they [stop] praying and [take] a step back to the beginning. In the beginning there were no words. In the beginning there was the sound, and they all knew what that sound sounded like" 33 (Beloved 1997: 259). The hope of being able to relate her story to others really shows that Sethe has moved beyond her fixation with the past. Sympathy is shown among them, because "each woman has experienced violence, humiliation, and trauma, each gains the power to make connections between the speaker and her own tale. The women are able to heal each other collectively by first articulating their traumas and then learning to recognize and love the connections between them" (Romero 418). 
In the disordered society of plantation slavery in Beloved, slaves were denied written language and they had to repress their own stories and their painful memories. However, Paul and Sethe create a memory by sharing their stories with one another. Paul D has his own trauma to deal with, yet is willing to listen to Sethe's and lay his story down beside hers so that their fragmented memories together can create something coherent (Beloved 273). So Paul D, by inviting Sethe to narrate her trauma, restores her and also helps her in reconnecting with the community. Beloved's presence like Paul D stirs up repressed memories in Sethe.

With mutual understanding and compassion, the community could replace oppression and silence. Morrison herself talks about the community and storytelling in the reestablishing of self: "The business of story-telling was a shared activity between them, and people of both genders participate in it at a very early age. We were encouraged to participate in it" (Mckay398). Sharing stories of their past experiences brings healing both to the listener and the speaker. This process of narration is essential for the survivors to come to terms with their experience. This narration ultimately creates a sort of emotional distance from the event and makes it less threatening for the characters to reflect upon. It is to be remembered that the authors make use of this technique of storytelling not just to heal the fractures of the readers in the modern psyche but also to rewrite a part of history forgotten by preserving the historical data, their cultural values and the AfroAmerican and Native American ideas.

Morrison regards the story of Beloved, as the essential story of the black experience in America. The characters are able to work their way back with their fellow African Americans and not be ultimately defeated by the poisonous residue of racism due to their love and support to one another. While Sethe's experiences mirror the suffering of the "sixty million and more" slaves to whom Morrison dedicates this novel, Beloved represents those who are not even counted in the official numbers in slavery.

The final words of the narrator in Beloved "This is not a story to pass on" (275) urges the revisiting of the trauma. Moreover, it retrieves the connection between the traumatic past, present and future. The connection among them should be more meaningful, which means when those who are traumatized can illustrate their own traumatic pasts just like telling old stories to others instead of isolating themselves from making a contact with others; they truly work through their own trauma. They are also capable of distinguishing what belongs to the past from the present.

\section{Historical Memory and Healing Narratives in Louise Erdrich's Novels}

Morrison and Erdrich understand that if one is still haunted in the painful past, one's sense of time will mainly linger around that and will be unable to connect with the present. Those who have endured physical abuse as well as psychological and emotional hardships try to block out the painful past thereby hindering their ability to live in the present. Through the novels characters', the novelists undertake to narrate how modern readers can learn to survive bringing the traumatized past into consciousness. The protagonists work through their personal trauma as a community in reconstructing the broken self-identity. It is to be remembered that in making use of the technique of storytelling the novelists not only heal the fractured self of the readers in the modern psyche but also rewrite a part of history forgotten in the official documentation by preserving the historical data, their cultural values and the Afro-American and Native American legacies. 
"Erdrich's own experiences with both family narrative and the Ojibwa oral tradition have shaped her desire to present her stories in the voices of storytellers, and through her representation of characters as storytellers, she transforms her readers to listeners" Stookey(13). Tracks(1988) draws on a number of oral storytelling strategy which include the "outsiders" as the audience and thus converts "readers" to "listeners" to narrate the tragedy of forceful dislocation. Having a faultless memory would be helpful in order to follow the frequent time shifts and muddled relationships of these various characters. There are so many diverse threads to the story that it is easy to get lost or confused, and the plot is so densely woven that at first a reader may have difficulty making connections. Apart from Erdrich's use of oral storytelling strategies, Jennifer Sergi argues that she also chronicles the story of the Chippewa's struggle to preserve their land and culture she also documents Indian storytelling.

For Nanapush in Tracks, storytelling is a ritual through which he brings Lulu back to Fleur, the mother. Nanapush's mission is to bring Lulu to her origins because he knows that Lulu must understand her origins if she is to understand herself. The reader is constantly reminded that Nanapush addresses his entire narrative to his granddaughter, Lulu. In the novel, Tracks the trickster/patriarch Nanapush narrates to young Lulu the story of the tribe's struggles in an attempt to give her back the identity she has lost while away at a government boarding school. Fleur assumed that her mother abandoned her to Nanapush to be raised. But Nanapush knows the vital importance of the narration of story and he insists that Lulu listens.

In Louise Erdrich's novel Tracks, Lulu's mother Fleur is represented as a person of a reclaimed past, something not irrevocable in the past, but present in memory, a memory so vital because it was so inextricably bound up with the community. Nanapush attempts to recount the tribe's own history in order to reconcile her completely with her mother. "Granddaughter, you are the child of the invisible, the ones who disappeared ..." (Tracks 2).

Shelley Reid argues that Erdrich captures the multiple voices and extended family networks of Native American individuals through her storytelling. Her narratives also allow the representation of a larger community identity and integrate her audience into the fabric of this extended family and its stories of survival. Pauline's narration, a representative of the mixedbloods, compared with that of Nanapush is that of an act of self-creation. Erdrich's fiction operates as a collective group of articulation, providing a voice for a minority community and one that promotes the potential of that community to attain their freedom. The collective appeal for that group is achieved in a larger part through the effective use of native story-telling techniques, mythology and everyday events with which people can identify themselves with their cultural background and also their daily lives. The author permits Nanapush and Pauline to tell stories about the connections of family, clan, and tribe. This technique seems to be common to Native American writers.

Tracks narrates the truth about the brutality of that extermination policy and provides the reader exactly with what good storytelling always provides: a recollection which gives the reader an opportunity or chance to heal; and an understanding and empathy, which one gets as one walks through the often messy and always fragile web of interconnections and relationships that define what it means to be a mother, to be part of a family, and part of a tribal community.

Erdrich stresses the significance of self articulation in oneself from the very beginning of the novel. Nanapush uses language to fend off Death. Nanapush defeats Death by "starting a story" and not letting Death "get a word in edgewise" (Tracks 46). He saves lives through storytelling --his own and Fleur in the outburst of spotted sickness: "They're(stories) all attached, 
and once I start there is no end to telling because they're hooked from one side to the other, mouth to tail. During the year of sickness, when I was the last one left, I saved myself by starting a story" (46). Therefore, for Nanapush, to tell stories is a means of survival.

Fleur, the central character is represented as a reclaimed past, something not irrevocably in the past, but present in memory, a memory so vital for the recovery of Lulu because it so inextricably bound up with her history. When the lumber company started cutting down the trees near Fleur's cabin, desperate, she sends Lulu to the government school for the sake of safety and plots her revenge. Secretly, she has sawed the trees around her cabin at the base, so that they remain lightly held. When the lumber company's men come to move Fleur by force the trees tumble down, crushing men and wagons beneath them. Finally, Fleur leaves her home ground but after carrying out her 'revenge' and confronting the ordeal.

The patriarch Nanapush narrates to young Lulu the story of the tribe's struggles in an attempt to give her back the identity she has lost while away at a government boarding school. "Granddaughter, you are the child of the invisible, the ones who disappeared when, along with the first bitter punishments of early winter, a new sickness swept down" (Tracks2). Nanapush explains to Lulu the fighting spirit of her mother, a woman who left the reservation only after taking revenge on the white men who forced her out. Erdrich, like Morrison has an intense interest in the past, how the past and present intertwine and inform each other. The need for memory is as important as the need for storytelling. Like Morrison, Erdrich's Nanapush must tell pass on the story to Lulu.

Tradition depends on memory, thus traditional storytelling depends on memory. And memory like storytelling has a collaborative aspect. Nanapush speaks about memory stimulation which can fill up the voids in another memory. He acknowledges the time when he saves Fleur from tuberculosis and as she regains her capacity for speech, she begins to remember her family, helping Nanapush to remember:"With her memory, mine came back, only too sharp"(Tracks 5)

Sharing of stories is a traditional native practice that provides a vehicle for learning and healing. Stookey observes of Erdrich "the strong sense of community expressed in all her work obviously reflects features of the writer's own experiences and background" (Stookey 10). Through Nanapush, Erdrich shows most effectively, the key to a sustained identity and collective and individual memory, which takes shape in the form of his storytelling. He recognizes the redeeming value of stories in those times: "during the year of sickness, when I was the last one left, I saved myself by starting a story. I got well by talking. Death could not get a word in edgewise, grew discouraged and traveled on (Tracks 46)

In the tradition of other contemporary women writer, particularly Toni Morrison, Erdrich uses memory and the past as a means of self-recovery. Mckay sees rewriting the traumatic history of African-Americans as "a conscious act toward healing a painful wound .... [and] to remind us never to let this atrocity happen again" (3). In case of Nanapush, there is strength in memory. The story is told in random, the voice of the last remaining, the voice of the past, for whom memory is the key to survival. Nanapush knows the urgency of telling one's own story. Knows that it has to do with one's self awareness, and there is strength in self-knowledge, self-definition. Lulu later comes to term because it is only in Nanapush's memory that Lulu can find her mother and the cause of her abandonment. Lulu, growing up in the middle of her mother's struggles but educated at the government school is segregated from her traditional heritage. Nanapush exhorts her to seek out Fleur, and she is inevitably reintroduced to her roots and the destiny of her people. 
Therefore in narrating the past to Lulu, Nanapush carries out the responsibility of telling Lulu her mother's story which is really the story of their own tribe. He readily admits, all stories are “. . . attached, and once I start, there is no end to telling because they're hooked from one side to the other, mouth to tail" (46). His articulation suggests that it is part of a long chain of storytelling as it reconstructs and transmits Fleur's past and the tribulations of the Chippewas over the years. His life revolves around the storytelling, and is inseparable from it. With each of his new recounting, he adds one more detail to the whole thing revealing an understanding of the past. Through the flow of his voice, stories of the old days intermingle with stories of the present- stories that are his own and of his people.

\section{Conclusion}

This paper illuminates the significance of healing through the participatory narration as identity is created and sustained through storytelling. Since language is a medium of power, writings from the margin define itself by rejecting the language of the Centre and by supplanting it with their own. In order to write specifically African American literature and revisit the nation's history, the writer must reject the language of the dominant culture which created a form of oppression for both African American literature and its criticism. Morrison through the inclusion of call and response dialogues and occurrences of black grammar rejects white mainstream language.

Further, Morrison proves that the essence and power of Afro-American tradition is in their own language which is most capable of expressing their history because the oppression experienced cannot be fully expressed by means of mainstream linguistic form. Therefore, particularly the collective speaking and black characters' language is the most effective means to retell their own history. Language in Morrison's novels functions not only as means of communication and passing on black history, but it also helps them to feel relieved of traumatic experiences.

In other words, her text generates within the reader a feeling of empowerment and a critical consciousness to protest, to parody and to empathize with the centuries of wounds inflicted on them. Through the participatory language of novel and non-linear narratives her representative writing reconstructs the stereotypes in histories. Perhaps then, her novel could be rightly described as an illustration of resistant literature with a commitment to redefine the racial differences prevalent in the nation. Language in her novels is then not simply a means of communication through words and gestures only but an expression which links what happened in the past generations with the present generation. Thus her novel does demonstrate ways in which language not only merely reflects the world, but can also directly affect it.

To sum up, the characters' acts of rememory restores back their sense of self which reconnects them to their psychological and historical past. This enables them also to reclaim the strengths which they exhibit as a way of moving on toward the future. By reciting their trauma, the protagonists begin to re-examine their own psychological nature and the strengths that ensured their survival. Besides this they were aware of the losses they would have to face in order to mend their fragmented sense of self.

Morrison's and Erdrich's novels ask the readers not only to remember the enslavement and colonization of the black nation, but also to remember those victims around the world who have lost their identities and their sense of worth because of their social environment. Like the protagonists in the novels, ignoring these wounds will only cause delay in the healing and 
leave deeper scars. On the other hand, open confession of the traumatic events would help the victim regain his lost identity.

Though boundaries cannot be drawn for further studies on Erdrich and Morrison, understanding the novels in the light of transgenerational trauma would make a very interesting reading. The study has rather opened new avenues for further research in the area of transgenerational trauma.

\section{References}

Allen, Paula Gunn. (1983). Studies in American Indian Literature. New York, NY: MLAA

Anderson, Melanie(2013). Spectrality in the novels of Toni Morrison. Knoxville : University of Tennessee Press.

Ann Hostetler(2014). "Resurrecting the Dead Girl : Modernism and the Problem of. History in Beloved, Jazz, and Paradise." Toni Morrison: Memory and Meaning.( Eds.) Seward, Adrienne Lanier and Justine Tally. Jackson: University Press of Mississippi.

Carmean, Karen. (1993).Toni Morrison's World of Fiction. Troy, NY: Whitson.

Diena, Simonetta. (2007)."Private Memories and Historical Studies: problems of Identity in the Survivors of the Holocaust." Journal of Psychoanalysis 49: 313-315.

Erdrich, Louise. (1988).Tracks. New York, NY: Harper \& Rowe.

Fulmer, Jacqueline (2007), Folk Women and Indirection in Morrison, Ni Dhuibhne, Hurston, an Lavin, Aldershot, Ashgate, University of California - Berkeley, USA

Grewal, Gurleen. (1996).Circles of Sorrow, Lines of Struggle. Boston: Northeastern University Press.

Herman, Judith Lewis.(1997).Trauma and Recovery: The Aftermath of Violence from Domestic Abuse to Political Terror. Basic Books.

Mckay, Nellie y. (1988). Ed. Critical Essays on Toni Morrison. Boston: G.K. Hall.

Morrison, Toni. (1988). Beloved. New York, NY: Plume/Penguin.

Rain water, Catherine.(2002). Narrativity in the Fiction of Louise Erdrich. New York: Oxford University Press.

Reid, Shelly. (2000). “The Stories We Tell: Louise Erdrich's Identity Narratives.” MELUS 25·3-4: 65-86.

Riley, Patricia. Growing Up Native America. New York, NY: Harper Collins, 1995.

Romero, Channette. "Creating the Beloved Community: Religion, Race, and Nation in Toni Morrison's Paradise." African American Review, Vol. 39, No. 3 (Fall, 2005), pp. 415-430

Rosenblatt, Paul. C (2014) The Impact of Racism on African American Families: Literature as Social Science Literature as Social Science. Ashgate, Burlington, USA

Sergi, Jennifer. "Storytelling: Tradition and Preservation in Louise Erdrich's Tracks." World Literature Today 66, no. 2 (1992): 279-283. Print.

Schreiber, Evelyn Jaffe (2010) Race, Trauma, and Home in the Novels of Toni Morrison. Louisiana State University Press.

Stookey. L. Lorena. Louise Erdrich: A Critical Companion. Westport: Greenwood Press, 1999.

Taylor-Guthrie, Danille (1994) Ed. In Conversations with Toni Morrison. Jackson: University Press of Mississippi. 